\title{
Formation of estimate cost of road-repairing works with the use of composite cationic bituminous structures
}

\author{
Andrei Ovsiannikov ${ }^{1}$, Anna Vorotyntseva ${ }^{1,{ }^{*}}$ and Vladimir Bolgov ${ }^{1}$ \\ ${ }^{1}$ Voronezh State Technical University, Moscow Avenue, 14, Voronezh, 394026, Russia
}

\begin{abstract}
The necessity of the formation of the estimated costs for the production of road-repairing works with the use of composite cationic bituminous structures is dictated by the lack of this kind of works in existing estimated costs base, because this type of materials has not been used yet. Estimated costs are intended both for the determination of the road-repairing work costs and to justify the effectiveness of the use of a new type of materials. This article describes the main concepts associated with the formation of estimate costs base for the determination of the road-repairing work costs. It also shows the formation of norms and prices for the installation of coatings with the use of composite compounds based on cationic bituminous structures.
\end{abstract}

\section{Introduction}

Modern estimate and normative base of pricing in construction is the basis for the determination of the cost of road-repairing works, in particular, road-construction works.

But current system cannot cover the entire range of materials which are used in modern constructions, in particular, new materials, which were not used in construction at all or in certain types of construction works.

The formation of estimate cost norms and prices for the road-repairing work with the use of new technologies, in particular, with the use of composite cationic bituminous structures is dictated by the fact of the presence of a number of advantages of this type of material over traditional technologies of hot and cold road asphalting:

1. There is no need in adherence to temperature conditions, due to the fact that this method can be used either in worm or in cold weather conditions. The repairing of road cover can be produced in high humidity conditions at positive ambient temperatures [1].

2. You can exploit roads 2 hours after finishing repairing works, which is especially actual on increased workload roads [2].

3. The value of bitumen using is highly reduced compared to hot and cold asphalt-concrete mixtures structure [3].

\footnotetext{
*Corresponding author: allslavin@mail.ru
} 
4. The use of previously recorded cover becomes possible, which significantly reduces prime cost and increases ecological effect, reduces the measure of road repairing construction's waste [4].

5. It eliminates the need for additional installation of coatings of hot and cold asphaltconcrete mixtures similar to existing technology of road installation with recycling using [5]. 6. The coating is more durable than hot and cold asphalt paving (alternative covers are usually used for 5 years, though hot and cold asphalt paving's life time is only 3 years, which highly increases the economic effect of using offered technology) [6].

7. Covers with composite structures based on cationic bituminous emulsions in all types of repairing works gives more durable result compared with traditional technologies due to the fact of better grip [6].

This paper shows the process of formation of prices for road repairing works with the use of composite cationic bituminous structures, and also gives a comparison of work costs for road repairing installations with the use of new materials and traditional methods of hot and cold asphalt-concrete mixtures.

\section{Materials and Methods}

There are several ways to define the road works cost. We used the method of the cost determination based on estimated specifications compiling, which includes:

1. The development of elemental estimated specifications;

2. The determination of estimated prices for used resources;

3. The formation of unitary prices.

Estimated specifications is the complex of estimated prices, which are used for determination of estimated construct costs along with rules and contributions, which include necessary regulations [7]. The main estimated normative, used for road work cost's determination is estimated price, which represents the amount of funds, sufficient for all resources purchase (material, labor and technical), which are necessary for execution special work types $[3,9,10]$. The scheme of prices formation is represented on figure 1 .
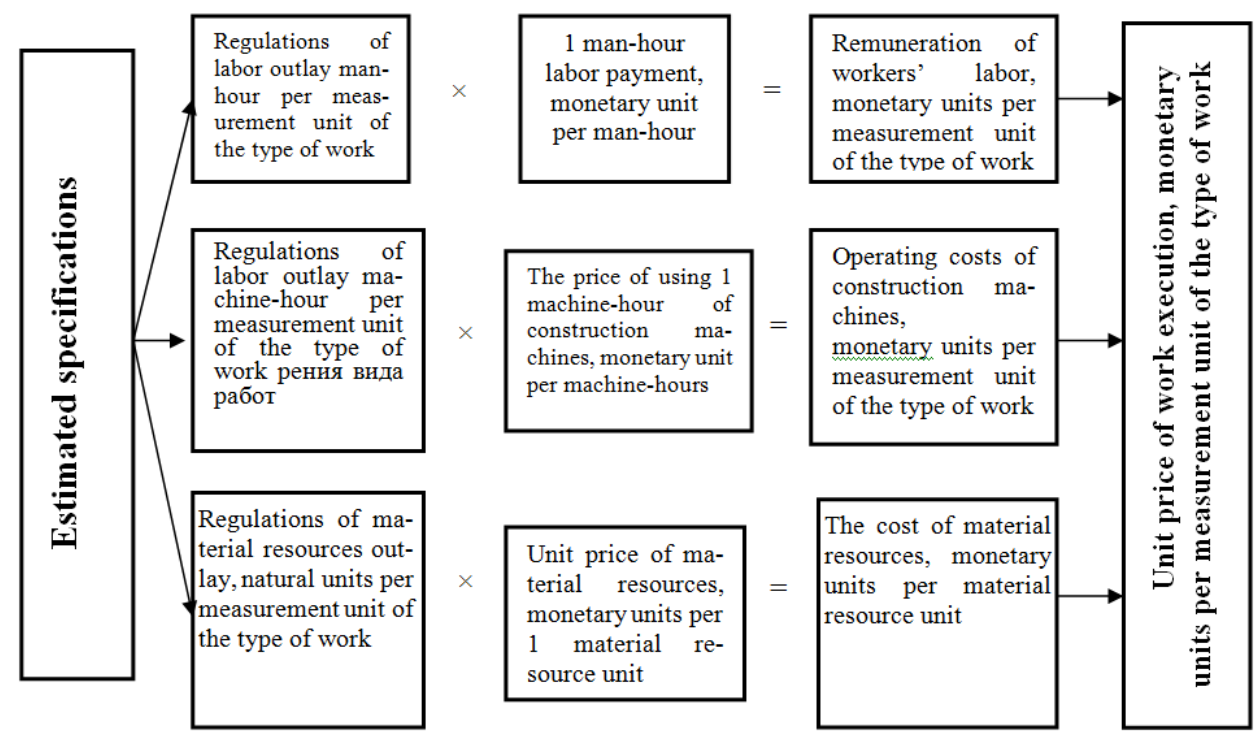

Fig. 1. Forming prices scheme. 


\section{Results}

Estimated specifications are developed for every several measurer of constructioninstallation and road repairing works. In the reviewing case we will use $1000 \mathrm{~m} 2$ unit of measurement, which suggests work's execution in value of $70 \mathrm{~m} 3$ with thickness of the covering of $7 \mathrm{~cm}$ and extension of the road about $167 \mathrm{~m}$ with middle width of the road of 6 $\mathrm{m}$. While forming the prices, we use current normative base, corrected to the current price level and represented in dollar equivalent, which was motivated by the possibility of applying this technology not only in Russian Federation but also abroad.

The forming of estimated specifications for new types of work (recycling and coverings with using composite structures had first priority, due to the fact that hot and cold coverings already have their prices.

The consumption and price of materials needed to perform road repairing works in different ways are shown in Table 1.

We offer Germany's company's WIRTGEN productions as main equipment for work producing. It was rather efficient while used on road constructing machine market. This equipment allows to solve wide range of tasks, such as strengthen the soil and road covers installations. You can get high-class building material, instead of low quality soil, with the help of this machines.

Additives and binders are cement, lime and water. Working as a cold recycler, WR series machines transform worn out layers of asphalt-concrete into high-class layers with a large bearing capacity, regardless of their size and layers thickness. The most suitable for our needs is WR 200 machine. We calculated the cost of machine-hours is $\$ 169.45$, and the estimated rate -1.67 machine-hours for $1000 \mathrm{~m} 2$ of pavement.

Table 1. Volume and price of materials used.

\begin{tabular}{|c|c|c|c|c|}
\hline \multirow[b]{2}{*}{$\begin{array}{l}\text { Name of } \\
\text { materials }\end{array}$} & \multicolumn{3}{|c|}{ Consumptoin of materials, $\mathrm{m} 3$ for $100 \mathrm{~m} 3$ of cover } & \multirow[b]{2}{*}{$\begin{array}{l}\text { Price in } \\
\text { dollars per } \\
1 \text { ton }\end{array}$} \\
\hline & $\begin{array}{l}\text { Hot asphalt- } \\
\text { concrete mixes }\end{array}$ & $\begin{array}{l}\text { Cold asphalt- } \\
\text { concrete mixes }\end{array}$ & $\begin{array}{l}\text { Composite cationic } \\
\text { bituminous } \\
\text { structures }\end{array}$ & \\
\hline Cement & 2 & - & 3 & 100 \\
\hline Sand & - & 14 & - & 15 \\
\hline Bitumen & 5,5 & 6 & 2 (for emulsifying) & 160 \\
\hline Diesel fuel & - & 3 & & 630 \\
\hline $\begin{array}{l}\text { Butadiene-styrene } \\
\text { thermoplastic } \\
\text { elastomer }\end{array}$ & - & 0,2 & - & 200 \\
\hline Macadam & 92,5 & 76,8 & 27 & 20 \\
\hline Water & - & - & 2 (for emulsifying) & 0,5 \\
\hline Asphalt granulate & - & - & 66 & 0 \\
\hline Emulsifier & - & - & 0,05 (for emulsifying) & 800 \\
\hline
\end{tabular}

Following estimated specifications have been developed on the base of presented data and pre-existing estimated standards:

1. Disassembly of asphalt-concrete covers and foundations with later processing of removed layer - recycling, $1000 \mathrm{~m} 3$ (Table 2).

2. Design of covers with use of composite cationic bituminous structures (Table 3 ) (The cost of recycling is equal to the cost of removing and processing the worn-out layer work and it is included in the cost of previous work). 
Table 2. Development of asphalt-concrete covers and foundations with later processing of removed layer-recycling, $1000 \mathrm{~m} 2$.

\begin{tabular}{|l|c|c|}
\hline \multicolumn{1}{|c|}{ Name of resource } & Units & Amount \\
\hline Recycling tools - machines WR 200 & Machine-hour & 1,67 \\
\hline Machinist's labor cost & Man-hour & 1,67 \\
\hline
\end{tabular}

Table 3. Design of covers with use of composite cationic bituminous structures, $1000 \mathrm{~m} 2$.

\begin{tabular}{|l|c|c|}
\hline \multicolumn{1}{|c|}{ Name of resource } & Units & Amount \\
\hline Workers labor costs (middle 2,9) & Man-hour & 61,84 \\
\hline Machinists labor costs & Man-hour & 6,53 \\
\hline $\begin{array}{l}\text { Automotive cranes at work on other types of construction } \\
10 \mathrm{t}\end{array}$ & Machine-hour & 0,04 \\
\hline Hand sprayers & Machine-hour & 0,56 \\
\hline Road rollers. Self-propelled, smooth & Machine-hour & 2,55 \\
\hline Asphalt concrete pavers & Machine-hour & 3,19 \\
\hline Tractor with mounted road brushes & Machine-hour & 0,75 \\
\hline Board cars, capacity 5t & Machine-hour & 0,07 \\
\hline Kerosene for technical purposes, brands KT-1, KT-2 & $\mathrm{t}$ & 0,00059 \\
\hline Square billets forgings, weight: 1,8 kg & $\mathrm{t}$ & 0,00613 \\
\hline Bitumen & $\mathrm{t}$ & 0,14 \\
\hline $\begin{array}{l}\text { Bars softwood length: 4-6,5 m, wideness 75-150 mm, } \\
\text { thickness 40-75 mm, III grade }\end{array}$ & $\mathrm{m} 3$ & 0,15 \\
\hline Asphalt concrete mixture & $\mathrm{t}$ & 165 \\
\hline
\end{tabular}

Estimated prices for new and pre-existing types of work are listed in Table 4.

\section{Discussions}

Estimated calculations for producing works were built on the basis of prices represented in Table 4, there are three compared methods.

Following results for the unit cost of $1 \mathrm{~m} 2$ of pavement were obtained on the basis of the estimated calculations:

- hot asphalt concrete mixtures - 3,30 \$, including materials $-2,16 \$$;

- cold asphalt concrete mixtures - 4,52 \$, including materials - 3,42\$;

- composite cationic bituminous structures - 1,46\$, including materials - 0,88 \$.

Economical effect of composite cationic bituminous structures installing makes up comparing:

- to use of hot coverings $-1,87 \$$, including materials $-1,28 \$$;

- to use of cold coverings $-3,09 \$$, including materials $-2,54 \$$.

Using suggested technology of producing road covering attracts economy in value 11200$18500 \$$ per $1 \mathrm{~km}$ of repaired roads, consequently $[8,9,10]$.

To form current estimate costs of road-repairing works in different regions of Russian Federation it is recommended to transit from the base-index method of the cost determination to a resource method of the calculation of estimated costs.

The transition to the new politics of pricing in road-repairing works sphere should lead to a better and more reliable determination of work-repairing costs. 
Table 4. Producing road repairing work prices with the compared methods (per $1000 \mathrm{~m} 2$ ).

\begin{tabular}{|c|c|c|c|c|c|c|c|}
\hline \multirow[b]{2}{*}{$\mathbf{N}$} & \multirow{2}{*}{$\begin{array}{l}\text { Denomination and } \\
\text { characteristic of } \\
\text { construction works }\end{array}$} & \multirow{2}{*}{$\begin{array}{l}\text { Direct } \\
\text { costs, } \\
\text { dollar. }\end{array}$} & \multicolumn{4}{|c|}{ Including, dollar. } & \multirow{2}{*}{$\begin{array}{c}\text { Workers } \\
\text { Labor } \\
\text { costs, } \\
\text { man- } \\
\text { hours }\end{array}$} \\
\hline & & & $\begin{array}{l}\text { Workers } \\
\text { salary }\end{array}$ & \multicolumn{2}{|c|}{$\begin{array}{l}\text { Machine } \\
\text { exploitation }\end{array}$} & Materials & \\
\hline \multicolumn{8}{|c|}{ Asphalt-concrete coverings and foundations dismantling } \\
\hline 1 & $\begin{array}{l}\text { Followed by the removal of } \\
\text { the pulled off layer }\end{array}$ & 1344,79 & 449,99 & 894,80 & 98,17 & & 214,82 \\
\hline 2 & $\begin{array}{l}\text { Followed by the removal of } \\
\text { the pulled off layer with } \\
\text { shipment }\end{array}$ & 841,60 & 315,10 & 526,50 & 102,95 & & 125,86 \\
\hline 3 & Followed by recycling & 282,98 & & 282,98 & 11,69 & & \\
\hline \multicolumn{8}{|c|}{ Coverings design } \\
\hline 4 & $\begin{array}{l}\text { Hot asphalt-concrete } \\
\text { mixtures }\end{array}$ & 2454,65 & 78,80 & 216,90 & 55,37 & 2158,95 & 67,025 \\
\hline 5 & $\begin{array}{l}\text { Cold asphalt-concrete } \\
\text { mixtures }\end{array}$ & 3680,80 & 185,48 & 79,32 & 17,90 & 3416,00 & 61,84 \\
\hline 6 & $\begin{array}{l}\text { With using composite of } \\
\text { cationic bituminous } \\
\text { emulsions }\end{array}$ & 1149,75 & 185,48 & 79,32 & 17,90 & 884,95 & 61,84 \\
\hline
\end{tabular}

The basis of the system of formation current price level should not be indexes of resources price changes, but the actual price level for various construction resources in the context of the constituent entities of the Russian Federation formed in the Federal State Information System for Building Pricing (FS ISBP) (Figure 2).

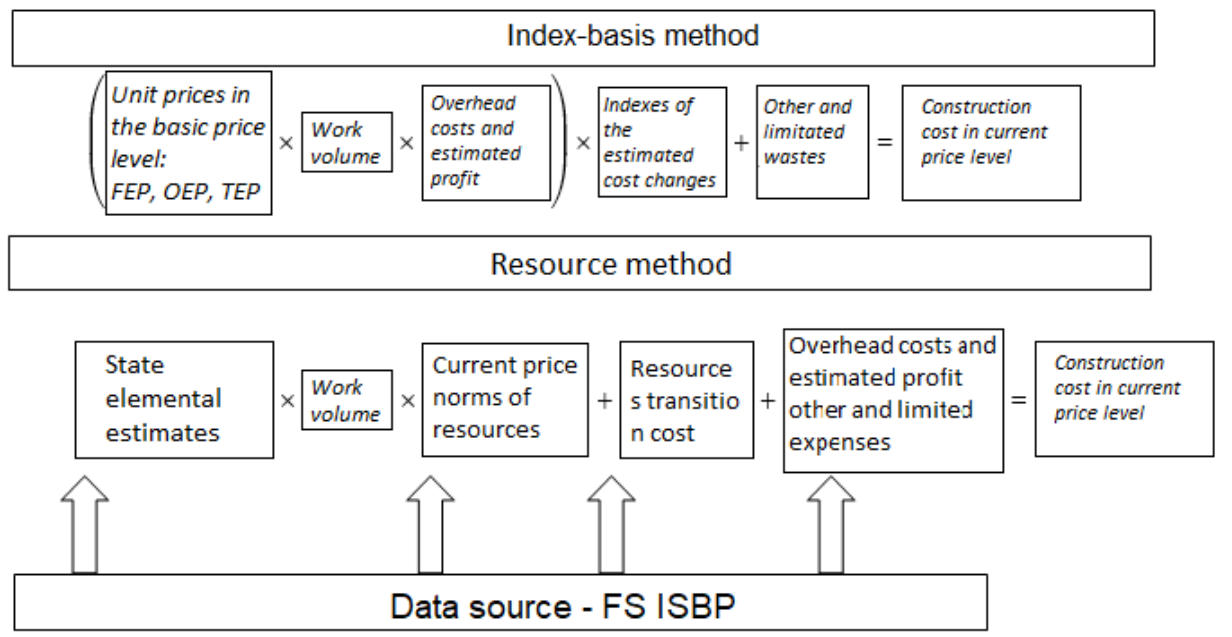

Fig. 2. Determination of construction estimated costs methods.

The use of resource method of the determination of construction estimated costs method can increase the correctness of cost calculations and to determine the actual costs of work more reliably. 


\section{Conclusion}

Applying this new method based on using composite of cationic bituminous emulsions and recyclingtechnology can help to reduce time limits for producing repairing works of road covering and their prompt commissioning. It can help to produce repairing works regardless of the climatic conditions, to provide economic and ecologic effect.

\section{References}

1. M. Aladdess, Engineering Systems and Structures 3(16), 38-43 (2014)

2. A. Vorotynseva, M. Aladess, Finances, Economics, Strategy 6, 48-54 (2016)

3. V. Gasilov, A. Vorotynseva, A. Ovsiannikov, Estimated work in constructing: tutorial (Voronezh State University of architecture and construction, Voronezh, 2016)

4. Public elemental estimate standards 81-02-27-2001. Car roads (The Ministry of Construction and Housing and Communal Services of Russian Federation, Moscow, 2014)

5. A. Ovsiannikov, A. Vorotynseva, D. Kuzmina, Pricing and budget normalization in the construction of: practical work (Voronezh State University of architecture and construction, Voronezh, 2016)

6. V. Podolskiy, M. Aladess, Engineering Systems and Structures 4(17), 96-105 (2014)

7. Federal unit prices. 81-02-27-2001. Car roads (The Ministry of Construction and Housing and Communal Services of Russian Federation, Moscow, 2014)

8. A. Chomicz-Kowalska, K. Maciejewski, Procedia Engineering 108, 436-444 (2015)

9. A. Vorotynseva, A. Ovsiannikov, V. Bolgov, MATEC Web of Conferences (2017) DOI: 10.1051/matecconf/201710608037

10. O.V. Didkovskaya, O.A. Mamayeva, M.V. Ilyina, Procedia Engineering 153, 131-135 (2016) 